\title{
Teachers' discourses of literacy as social practice in advantaged and disadvantaged early childhood contexts
}

\begin{tabular}{|c|c|}
\hline \multicolumn{2}{|c|}{$\begin{array}{l}\text { Authors: } \\
\text { Colwyn D. Martin }{ }^{1} \text { (1) } \\
\text { Hasina B. Ebrahim² }\end{array}$} \\
\hline \multicolumn{2}{|c|}{$\begin{array}{l}\text { Affiliations: } \\
\text { }{ }^{1} \text { Department of Early } \\
\text { Childhood Education, } \\
\text { University of the Free State, } \\
\text { South Africa }\end{array}$} \\
\hline \multicolumn{2}{|c|}{$\begin{array}{l}{ }^{2} \text { Department of Early } \\
\text { Childhood Education, } \\
\text { University of South Africa, } \\
\text { South Africa }\end{array}$} \\
\hline \multicolumn{2}{|c|}{$\begin{array}{l}\text { Corresponding author: } \\
\text { Colwyn Martin, } \\
\text { martincd@ufs.ac.za }\end{array}$} \\
\hline \multicolumn{2}{|c|}{$\begin{array}{l}\text { Dates: } \\
\text { Received: } 18 \text { May } 2016 \\
\text { Accepted: } 02 \text { Aug. } 2016 \\
\text { Published: } 29 \text { Nov. } 2016\end{array}$} \\
\hline \multicolumn{2}{|c|}{$\begin{array}{l}\text { How to cite this article: } \\
\text { Martin, C.D. \& Ebrahim, H.B., } \\
2016, \text { 'Teachers' discourses } \\
\text { of literacy as social practice in } \\
\text { advantaged and } \\
\text { disadvantaged early } \\
\text { childhood contexts', South } \\
\text { African Journal of Childhood } \\
\text { Education 6(2), a454. http:// } \\
\text { dx.doi.org/10.4102/sajce. } \\
\text { v6i2.454 }\end{array}$} \\
\hline \multicolumn{2}{|c|}{$\begin{array}{l}\text { Copyright: } \\
\text { ( 2016. The Authors. } \\
\text { Licensee: AOSIS. This work } \\
\text { is licensed under the } \\
\text { Creative Commons } \\
\text { Attribution License. }\end{array}$} \\
\hline \multicolumn{2}{|l|}{ Read online: } \\
\hline 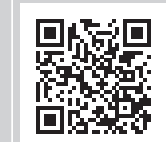 & $\begin{array}{l}\text { Scan this QR } \\
\text { code with your } \\
\text { smart phone or } \\
\text { mobile device } \\
\text { to read online. }\end{array}$ \\
\hline
\end{tabular}

This article examines two teachers' discourses of literacy as social practice in advantaged and disadvantaged early childhood centres for three- to four-year-olds. The intention is to make sense of the dominant discourse of literacy, its constitutive nature and its effects on children, teaching and learning. Foucault's theory of discourse is used to make salient the influence of interpretive frames of references on the understanding and practice of literacy. The data for the study was produced through a qualitative approach using in-depth semi-structured interviews. The findings show that teachers in both the advantaged and disadvantaged contexts are located in the dominant discourse of early literacy as a technical, autonomous skill. This discourse foregrounds children as adults-in-the-making (the becoming child) and a maturationist-environmentalist view of readiness for early literacy development. This narrow view of literacy discounts young children's positioning as social actors, issues of diversity and contextually situated practice.

\section{Introduction}

Like elsewhere in the world, early literacy in South Africa is considered a fundamental human right: a tool of personal empowerment and a means to educational, social, cultural and human development (Trudell et al. 2012). It is assumed that if we get early literacy right, then children's educational success would be assured, which would ultimately lead to social, cultural and human development. However, in South Africa, the nature and use of literacy, for whom, under which circumstances and for what purposes is highly contentious. Some of the reasons for this include the overwhelming hegemony of English, the unequal educational opportunities afforded to different children in different contexts, inadequate training of the workforce and the underpreparedness of teachers to teach in diverse contexts (Mashiya 2011; Sherry \& Draper 2013; Spaul 2013). This complicates the implementation of early literacy as a basic human right.

Taking the above into account, it is not surprising that the massive expansion of Grade R provision has had 'virtually no measurable impact for the poorest three school quintiles, while there are some impacts for the higher quintile schools' (Van der Berg et al. 2013). The authors argue that instead of reducing inequalities, Grade R extends further advantage to more affluent schools. The bottom three quintiles are further compromised with little to no effects on child outcomes, including literacy outcomes. The National Education and Evaluation Unit's (NEEDU) report on literacy teaching and learning in the Foundation Phase concur with these findings. The report revealed that the majority of children in the Foundation Phase lack basic literacy and numeracy skills (Department of Education 2012). For example, 72\% of the 'three best learners in Grade 2 were reading below the average benchmark for Grade 2 and 22\% were performing on or below the poor benchmark' (2012:10). This is also evident in the report on learner retention where the Department of Education notes that Grade 1 repetitions are the highest due to serious deficiencies in school entrants' learning and unsuitable learning programmes beyond the reach of many children's capacity (Department of Education 2012).

There is a compelling body of evidence that shows that if we are to improve the schooling success of all children, we need to provide them with a strong foundation prior to formal schooling (Ebrahim 2010; Meier 2014; Sherry \& Draper 2013). Two government-led initiatives are directed towards building strong foundations for early learning. Both these initiatives pay attention to early literacy for children from birth to four. The National Early Learning Standards (NELDS) came into effect in 2010 (Department of Education \& UNICEF 2009). It was specifically directed at promoting child-centred practices, holistic development and monitoring of early 
learning experiences. The literacy component focused on building effective communication and confidence in language use. The NELDS served as the catalyst for the development of the National Curriculum Framework (NCF). The NCF arose out of the need to address the fragmentation that characterised young children's early learning experiences (Department of Education \& UNICEF 2015). The NCF addresses early literacy through a broad focus on communication, which includes developmentally and culturally responsive listening, speaking, reading and writing. For the purpose of this article, Barton and Hamilton's (2000:8) definition of literacy is used, where literacy is defined as 'a set of social practices' that are observable events which are mediated by different types of texts.

In centre-based provision, the success of any intervention partly relies on the competence of teachers to deliver highquality early literacy experiences. For the purpose of this article, the social practice view of literacy is defined as a concrete human activity that involves what people do with literacy, the association they have with what they do, how they construct its value and the ideologies that surround it (Baynham \& Prinsloo 2009). It is at this level that underlying discourses that shape teachers frame of thinking and the way in which literacy is practised in a particular event become relevant.

Most research in literacy learning and literacy practices in early schooling highlights teachers and learners struggles with literacy in general and specifically with English and African languages (Pretorius \& Matchett 2004); teachers perspectives on teaching reading (Naidoo, Reddy \& Dorasamy 2014); teachers ability to teach reading (Spaul 2013); training programmes that fail to meet standards for teaching (Uys et al. 2007). While the focus of literacy research has been on literacy learning and teaching in formal schooling, little is known about teachers' understandings of literacy and how these understandings shape their practice in the early years prior to formal schooling. This article therefore fills a gap in knowledge in early literacy prior to Grade R. Specifically, it sheds light on how common discourses in two disparate early childhood centres function to construct the literate child. The small sample affords opportunities to create in-depth understanding of the key issues at hand.

\section{Theoretical framework}

This article is informed by the Foucauldian concepts of discourse, power/knowledge and subjectivity. A Foucauldian construct of discourse comprises the 'general domain of all statements and sometimes as a regulated practice that accounts for a number of statements' (Foucault 1972:80). In different discourses, statements come together in ways that are predictable and have depth, substance and consistency (Foucault 1972). As components of discourse, these statements are interrelated with systems of knowledge, which can be seen as effects of particular relations of power. Thus, discourse in a Foucauldian sense denotes both a body of knowledge or subject disciplines such as literacy, psychology or science and a set of practices that, when associated with a particular discipline work to construct specific objects, strategies and people in particular ways (Foucault 1972; 1980). There are multiple discourses at play at any given moment in time and inconsistencies and complexities exist within particular discourses. For example, in early childhood contexts, multiple discourses such as the school-ready child, literacy as skill and the becoming child (adult-in-the-making) all work together to construct literacy, children, teaching and learning in particular ways. The multiple and related discourses also cohere to form the dominant discourse which can be understood in the context of power and knowledge.

Foucault (1977) argues that 'power and knowledge directly imply one another; that there is no power relation without the correlative constitution of a field of knowledge, nor any knowledge that does not presuppose and constitute at the same time power relations' (1977:27). For Foucault (1977) power is everywhere, diffused and embodied in discourse and knowledge. Power works to [re]construct discourse; it is both a discourse and located within discourses (Foucault 1980). Foucault (1980) understood discourse to be the space where power and knowledge intersect. It is in this intersection that different types of power produce different types of knowledge that become 'regimes of truth' (Foucault 1977). How knowledge is constituted through the connection of discursive practices was significant for this study, as certain discourses are 'those points where it becomes capillary' and spreads out into other spaces (Foucault 1980:98). The 'points where it becomes capillary' or converges are made possible because of the dynamic relationship between power and knowledge (1980:98).

Foucault's (1984) theory of how individuals are constituted is significant to understand how the early childhood teachers constitute themselves and the young children in their classrooms. In addition, the concept of subject (Foucault 1982) is also significant where subject means 'subject to someone else by control and dependence, and tied to his own identity by a conscience or self-knowledge - both meanings indicate a form of power which subjugates and makes subject to' (1982:212). For example, the teachers constitute a literate child as one who needs to speak English only at school. However, at different times and in different spaces, children either resisted or conformed to the hegemonic practice of only speaking English at school. Ball maintains that the notion of subjectivity is the 'possibility of a lived experience within a context' where the 'real basis of the self is both agent and object' (Ball 2013:125; McGushin 2011:19). As both an agent and object we are constituted within this double bind (Ball 2013).

\section{Methodology}

This article is based on part of a doctoral study that examined literacy as social practice from the perspective of teachers' discourses in both advantaged and disadvantaged contexts. 
Since an examination of discourses is best facilitated through critical engagement with the subjective experiences and perspectives to make sense of meanings (Cohen, Manion \& Morrison 2011; Maykut \& Morehouse 1994), a qualitative research design with an ethnographic approach was most suitable. This approach afforded opportunities to develop an in-depth account of meanings. It also supported the need to understand how discourse, power and knowledge intersect to construct the subjectivity of the literate child.

A purposive sampling strategy was most appropriate for the study as it called for the creation of a sample based on 'typicality or possession of particular characteristics being sought' (Cohen et al. 2011:156). There were several criteria that informed the selection of the early childhood centres and the participants, namely number of participants, context, provision and age group. Since this study sought in-depth examination of discourses rather than generalisation, only two early teachers were selected: one from an advantaged context and the other from a disadvantaged context. At the start of the research study, meetings were held with the principals of the centres to determine whether the teachers and parent community would be amenable to my conducting the research at the two sites. The principals handed out letters of consent to the parent community and the teachers at the centres. The consent letters included a brief explanation of the study, a description of the role of the teacher in the research process and a brief discussion of issues relating to anonymity and ethical considerations. Included in the consent letter was an option to withdraw from the study at any time should they so wish (Silverman 2009). Two teachers who worked with children between the ages of 3 and 4 were willing to pariticpate in the study.

The two teachers taught in contexts that were located in diverse racial, linguistic, religious and socio-economic contexts. The centres were privately run where one could be classified as middle-class and the other as catering for children from working-class backgrounds. The choice of the sites was based on what Foucault called real and ideal spaces (1977). An early childhood context can be viewed as a 'real space' that contains within it 'buildings, rooms, furniture', daily practices, routines that provide employment, care and education for young children, adequate nutrition, primary health care, employment etc., (Department of Basic Education 2012; Foucault 1977:148). An 'ideal space' is one that 'constructs rational classifications of human beings; how one was to observe, supervise, regulate ... through characterisations, assessments, and hierarchies' (1977:148). It is a space that represents power and ideology.

Teachers in the study were diverse in terms of race, language, social class and educational experiences. Teacher Shari, a black single working-class parent, was employed at Universal Early Childhood Centre, which catered for children from disadvantaged contexts. She spoke Sesotho and also had good communication skills in Afrikaans and English. Teacher Shari was unqualified and relied on training programmes organised by the Department of Education. Teacher Dee came from a white, middle-class, English background. She worked at Cheerful Tots, which catered for children from advantaged contexts. She was qualified with an undergraduate and postgraduate degree and a diploma in early childhood development. She also kept abreast with the latest developments in early childhood education.

This data for this article were generated through semistructured interviews. These types of interviews allowed for the identification of the cultural realities of the teacher's practices as well as enabling engagement with issues as they arose (Silverman 2009). One in-depth interview with each teacher was conducted. This was supplemented with subsequent conversations for clarification on specific issues. Once I had completed the transcriptions of the interview data, I had informal conversations with the teachers to make sense of what was said. These conversations allowed for the teachers to justify what they said or why they said what they said.

The questions for the semi-structured interviews were developed around the following themes:

- early experiences of becoming literate

- training and development and teaching experience

- constructions of literacy

- how children become literate

- the role of the early childhood practitioner in the construction of the literate learner

- early childhood literacy teaching

- problems experienced in teaching young children.

While I had a general idea or plan of how the interview would unfold, the questions only served as a guide as I allowed the teachers to dictate the way in which they wanted to respond. This guide served as an instrument midway between unstructured and structured interviews, depending on the kinds of responses that I received from the teachers (Cannold 2001). For example, I made use of structured questions when I asked the teachers about their training and experience. However, the follow-up questions provided the participants with the freedom to elaborate on how their training and experience influenced their practices.

Foucauldian ideas were used for the data analysis. While Foucault did not outline a process for doing discourse analysis, he did provide strategies and concepts that can be used when doing a genealogical discourse analysis (Foucault 1972; 1978; 1984). A genealogy is a historical method, where one looks for the history of the present by understanding how certain regimes of truth are sustained and legitimated over time. This provides an avenue for understanding how power circulates in 'the production of discourses and knowledge, and their power effects' (Carabine 2001:276).

Data analysis took place in three stages. The first stage examined discursive formations and the location of the object of the discourse. This stage involved the identification of different ways in which literacy was constituted. The focus 
fell on 'types of enunciations' or statements, which 'constitute the objects of which they speak' (Foucault 1972:54; 205). The second stage involved recognising the discourse and tracing its constitution. A review of secondary research that focused on early childhood literacy was conducted. The intention was to identify where the regimes of truth about literacy, learning, teaching and children originated. As Poster (1990) argues, Foucault's (1972) work regards a literary text as part of a larger framework of texts, institutions and practice. Within these bodies of knowledge are statements that validate and provide descriptions, specifications and expertise required to become literate in early childhood classrooms. In the third stage, the constructions of subjectivities and subject positions were analysed to determine what the statements do. In analysing the statements in the semi-structured interviews, it was possible to question the constitutive effects of what was being said to identify the unsaid. The discursive analytic proved useful to analyse literacy as social practice at the early childhood centres. I was able to move both in and out of the text by looking at the statements and enunciations, tracing the genealogy of the discourses by locating them within wider discourses and identifying how children and teachers take up multiple positions at the centres. In this way, I was able to move back and forth from theory to data and data to theory.

\section{Findings and discussion}

The larger study identified four definitional discourses, namely (1) literacy as skill, (2) the becoming child, (3) the good teacher and (4) the good parent. In summary, the dominant discourse of literacy as skill converged to produce the image of the literate child with specific skills, competencies and knowledge, which was situated within the wider discourse of child development and school readiness. In constructing the literate child in this way, the discourses of child development and readiness converged to form the subjectivity of the becoming child. The scientificity of child development and readiness assigned power to the teachers because they had knowledge of what constituted literacy and what a literate child should be able to do and know, and best practices to support literacy learning.

This power/knowledge nexus worked to produce the discursive formation of the good teacher. In addition, the subjectivity of the good teacher further legitimated the early childhood teachers' work as being about getting the child ready for school, thereby further producing the subjectivity of the becoming child. In the construction of the becoming child, the teachers had particular assumptions about the role that parents played in the facilitation of literacy development. They believed that it was important for parents to know about the importance of early childhood education, child development, speaking English in the home and providing healthy snacks for their children. This knowledge enabled the teachers to speak into existence the subjectivity of the good parent. Because parents did not have this knowledge, the early childhood teachers' expertise was further legitimated and their role in literacy learning was positioned as valuable.
Due to space limitations within the confines of this journal, this article reports on the first two discourses: literacy as skill and the becoming child.

\section{Literacy as skill}

The teachers' talk revealed taken-for-granted assumptions about what constituted literacy for children in their care. These assumptions created regimes of truth, which enabled what counts as literacy and how it was understood to become 'manifest, nameable and describable' (Foucault 1972:41). The excerpts below illustrate the construction of literacy as an autonomous skill:

\section{Teacher Dee:}

'I think ... it is communication - it is through doing, like acting, vocalising, and lots of conversations ... listening to others and responding to them ... through play, reading stories and reading on your own. If you cannot read and write as far as I am concerned you cannot learn. But it is also about being able to speak clearly and being able to listen and understand what is being said ... like when they listen to stories, when they talk to me or their little friends. Learning is all language based ... knowing the language ... reading, speaking and so on ...'

\section{Teacher Shari:}

'[Literacy is] reading and writing, listening, talking ... I think that they must be able to speak to you and to their friends; they must listen and answer questions.'

The statements above articulate what Foucault (1988a) terms social and discursive technologies that operated as a 'material series of processes ... system of ideas, concepts, values and beliefs' (Grosz 1990:63). These technologies authorise and sanction different sign systems that assigned particular meanings to the construction of literacy (Foucault 1988). As a discursive construction, literacy was defined and understood by both teachers in terms of a discrete set of individual skills or characteristics: 'listening, speaking, reading and writing, doing, acting, answer questions, understand what is being said'. This points to what children needed to acquire. The limited identification and location of literacy within the individual highlights the power relations inherent within the discursive construction of literacy as a skill.

This construction positions and constructs children in different ways, which inevitably leads to hierarchy and ranking of children against these normalising standards of literacy as a skill. Technologies of power such as standardisation, regulation, normalisation and ranking result from and maintain the discourse of literacy as skill. This is evident in the statement uttered by Teacher Dee: 'because if you cannot read and write as far as I am concerned you cannot learn'. Situating literacy within the human subject and the identification of skills and competencies required to become literate constructs the subjectivity of the literate child, which can invariably lead to positioning of different children as deficient in relation to the skills that they need to acquire. 
For example, if a child cannot read, write, listen, speak, etc., they cannot learn.

The legitimation of the autonomous model of literacy with its emphasis on individual, technical or neutral skills reveals the discursive shift towards the functional nature of literacy (Street 1984). Being functionally literate in ECD contexts requires the acquisition of individual skills needed to complete different literacy tasks and involves the ability to recognise the 'different sets of expectations needed for different types of communication' (Comber 1996:208). For example, the teachers spoke about how they paid full attention to what the schools expected early childhood centres to do for early literacy development. The power of this construction is evident when one considers how children are constructed to fulfil expectations and how hierarchies and ranking of children against normalising standards of literacy is operationalised. Technologies of power such as standardisation, regulation, normalisation and ranking result from and maintain the discourse of literacy as skill. For example, the teachers talked about being able to 'listen and answer questions; speak clearly; listen to stories' which shows how being literate in this context is primarily spoken of and measured in terms of identifiable skills required to perform efficiently within the classroom context.

\section{The becoming child - the ideal literate child}

An analysis of semi-structured interview texts showed that the literate child was constructed in a particular way with specific skills and competencies as well as visible sign systems, which were couched in the dominant discourses of child development and readiness. The discourses of the developing nature of the child and readiness traditionally positioned the child as becoming and incomplete in opposition to the adult as a complete being (Lee 2001). As argued by Lister (2007), the becoming child is consistent with the deficit model of children's developmental needs and their limited competencies. Within this context, the teacher's job is to 'facilitate and equip children with the skills and capacities required for full participation' in schooling (Lister 2007:701). This future-oriented construction of children in instrumentalist terms negates children's present-day capacities and potential. Consequently, the image of the subjectivity of the becoming child revealed that a child was constructed as being ready for learning and for school if he/she possessed certain knowledge and skills for their developmental age and conformed to expected and predicted subjectivities and characteristics of the school environment (Evans 2013).

An analysis of both the semi-structured interviews revealed an ideal literate child as one who:

- can sit and finish the work that they have to do

- pays attention

- sits still

- is an independent little body

- is able to speak quite clearly so that they can be understood

- is able to pronounce words clearly
- knows phonics ... sounds to be able to speak clearly

- learns through play

- can count to 10

- sings songs

- recites poems

- knows colours and shapes

- can cut and paste

- say bible verses

- answers questions

- listens

- looks at pictures and talks about what they see

- is able to use language in a particular way with other children and adults

- can communicate what they feel

- can express himself

- uses vocabulary to communicate

- picks up vocabulary incidentally.

The above utterances enabled certain 'rules or forms ... to become manifest' thereby constituting 'the objects of which they speak', namely the becoming literate subject/child (Foucault 1972:99-149). The teachers' constructions of how a literate child should look and act emphasised outputs and reduced literacy to a set of autonomous skills. For example, a literate child was one who could sit still, pay attention, answer questions, communicate etc. This educational knowledge of how a literate child should look and act worked as a 'technology of production' by putting into place 'practical grids of specification for diagramming, classifying and categorising' the literate subject (Foucault 1972:42; 1988:18). A literate subject was thus constructed as one who was able to procedurally display oral, written and bodily indicators such as sitting still, paying attention, using vocabulary to communicate, etc. (Unsworth 1988; 2001).

The teachers' construction of the literate subject shows how the discourse of literacy as skill collided and converged to produce the image of the becoming child. Two elements of teachers' discourses were located in the teacher's talk, viz., child development and readiness, that worked to construct the becoming child.

\section{Child development}

Cannella (1997), Baker (1998) and Moss (2012) among others maintain that child development discourse structures our understandings and conceptions of children in early childhood education. Burman (2008) concurs by saying that there are recognised ideas about the becoming child in early childhood education, which is characterised by an entrenched and unquestioning adherence to developmentalism. Developmentalism is a way of reasoning about humanity that was taken up in formal education in the late 19th century (Burman 2008). It offers a view of individuals in which new abilities and proficiencies were thought to unfold in set steps or were acquired through a series of stages (Baker 1998). In South Africa, child development discourse is afforded weight by different policy documents (See: Department of Education 2001; 2005; Department of Education \& UNICEF 2009; 
Department of Social Development 2006). For example, in White Paper Five on Early Childhood Education (Department of Education 2001) the image of the child as becoming is highly valued and early childhood services and programmes are required to cater for the child's emotional, social, intellectual, spiritual and moral development. This developmental discourse is given further weight by the following utterances of the teachers:

\section{Teacher Dee:}

'I believe that children at this age learn best in this way ... when all their senses are stimulated ... when you use art, music, song ... stories to help children to learn ... [you must know] what their needs are, what they enjoy doing ... their interests.'

\section{Teacher Shari:}

'[we must] know what is their age ... what they like to do, what they need ...'

Developmental theories purport an age-stage approach to children's progression (Berk 2009). As such a teacher must know about child development and practices that support learning, viz. developmentally appropriate practices (DAP). Knowing their 'needs, what they enjoy doing, their interests, how to stimulate their senses, know what is their age' are examples of DAP, which work to ensure that children achieve their developmental goals. As a technology of production, the 'scientificity' of child development knowledge assigned power to the teachers and gave them a privileged right from which to speak (Foucault 1988). Power was assigned to the early childhood teachers who saw their role as ensuring that children acquired the knowledge and skills needed for that particular stage of development.

Both teachers believed that their role was to develop the oral literacy skills of the children in their care. This belief was based on the perception that age was related to literacy development:

\section{Teacher Dee:}

'Children in my class are too small to read, so you have to read to them. They cannot really tell you what is in the story, so you have to read to them. I think it is only when a child starts reading that they are able to talk about the story.'

Teacher Shari:

'They can't read now. I read to them.'

The utterances point to the belief that being literate was about reading the word and that a child at this age was incapable of reading independently. These regimes of truth were based on child development discourse where a skilled literate child is one who grows and develops in stages (Foucault 1977). Consequently, children have to first develop oral literacy skills, as they were not yet ready for reading and writing. This ordering of progression can be linked to child development theory where each element of development builds on the others.
The utterances 'but they can't read now and they cannot really tell you what is in the story' reveals how the teachers assumed that development preceded literacy. It is also an indication of how the child was classified as deficient and not capable of making meaning of different kinds of texts. This classification was based on the belief that all children develop and grow in a linear fashion through universal ages and stages (Popkewitz \& Bloch 2001). Stern (2000) argues that children as young as 3 are able to develop their narrative self. By assuming that children were too young to read, the teachers disregarded how children see themselves as part of the story or how the story related to their everyday lives. The utterances also reveal how child development discourse intertwines and connects with developmentally appropriate practice discourse to construct the image of the becoming child. The statements because 'I have to read to them and I have to teach them how to write and draw and you have to read to them' determined the kinds of developmentally appropriate teaching and learning experiences required for children to become literate.

Power/knowledge was assigned to the teacher, as she was the expert who could guide children towards achieving basic skills thereby normalising the subjectivity of the becoming child. This unequal relation of power reveals how children's engagement and participation were relegated to the learning and development of specific skills that would help them to become ready for school. The assumption that all children can achieve the same level of development and all children go through the same developmental milestones constitutes a universal condition of children and childhood (Cannella 1997). These universal truths silence issues of diversity and reinforce unequal relations of power based on race, class or gender. In addition, by classifying the child as deficit in relation to sameness in terms of child development, the teachers discounted the ways in which children actively made sense of literacy experiences in their homes and communities.

\section{Readiness}

From the analysis of the semi-structured interviews, it was evident both the teachers' construction of the image of the becoming child was based on the idealist and/or nativist and empiricist and/or environmental conception of readiness (Meisels 1999). These two constructions of readiness did not exist in isolation, but rather they intersected and impacted on one another to produce the image of the becoming child.

An idealist and/or nativist conception of literacy sees readiness as a 'phenomenon that occurs within the child' (Evans 2013:172) where children are considered ready for learning if they have acquired particular developmental capacities (Kagan 2007). The empiricistand/or environmental conception of readiness is constructed around the belief that there are certain knowledge, skills and experiences children need to become ready for school (Brown 2010). The idealist and/or nativist conception of readiness conceptualises literacy development as occurring within the 
child and 'dependent on inherent, maturational processes' (Evans 2013:174). These understandings were evident in the following utterances of the teachers:

Teacher Dee:

'[some] children have poor eye-hand co-ordination or have not developed fine motor skills ... the children at this age are supposed to be able to speak quite clearly so that we can understand what they are saying.'

Teacher Shari:

'Well ... I think that he should be able to sit still and listen when I am talking. Also he must be able speak properly and be able to answer questions that I am asking him.'

The skills mentioned by the teachers: 'eye-hand co-ordination; speak clearly; sit still; listen and answer questions' are considered knowledge and skills that a child needs to be legitimated as ready for learning. Within this context children were considered ready for learning once they had acquired these individual developmental capacities. Examples of these included skills include 'pronounces words clearly; knows their phonics; answers questions; looks at pictures, can talk about what he/she sees'.

The utterances also revealed evidence of readiness within an empiricist/environmental framework. This understanding was based on the belief that readiness provided one with the necessary literacy knowledge, skills and learning experiences that were needed for formal schooling (Brown 2010). Both teachers believed that their role was to provide particular learning experiences so that the children could become school ready. For example, the teachers planned for different kinds of learning experiences to get the child ready for school:

Teacher Dee:

'[I] plan different kinds of activities ... to prepare them for the next class.'

\section{Teacher Shari:}

'I must make sure that they can do things in my class so that they know what to do in the next class. I plan my day like what I am going to do in the morning, what I am going to learn [teach] them for the day.'

This specific notion of readiness was thus constructed as 'a normative developmental goal' (Evans 2013:176). Power was allocated to the teachers as this educational knowledge enabled them to rank and classify children. Consequently, as shown below children who had not acquired these 'normative developmental goals' were provided with extra educational experiences and explicit teaching to train and correct the individual:

\section{Teacher Dee:}

'Most of my children are second language learners. I have organised extra English classes for them. We have a speech therapist who helps learners who have problems with speech - the children at this age are supposed to be able to speak quite clearly so that we can understand what they are saying. We also do monkeynastics ... this is for children who need to develop their gross motor and fine motor skills.'

\section{Teacher Shari:}

'I show them how to colour and then they must copy my picture ... I show them how to hold their crayons and they copy what I am doing. They must cut on the line and paste neatly on their page $\ldots$ and I observe each and every one of them, and when I see that there is a problem, I would help.'

Through surveillance and normalising judgments, children were classified as becoming school ready once they were capable of performing certain activities, for example speaking in English, pronouncing words clearly, developing fine and gross motor skills, colouring, holding crayons correctly, cutting, pasting, etc. In both contexts children were normalised if they 'conform $[e d]$ to a standard defining the normal' of what constituted a school-ready literate child (Foucault 1977:182). Normalising literate behaviour in terms of school readiness made it 'possible to control both the disciplinary order of the body and the aleatory [temporal] events that occur in the biological multiplicity' (1977:253). Thus, teachers were able to make pedagogic judgments of children by 'pinning down [of] each individual in his own particularity' (Foucault 1997:192), viz., second language English speakers, children who could not speak clearly, children who could not hold a crayon or could not colour, etc. These judgments enabled the teacher to 'fix [ing] individual differences' through speech therapy, extra English classes, demonstrations and children copying what the teacher had done (Foucault 1997:191).

The discourse of readiness also points to the complex nature of teachers' work. While the teachers' beliefs and practices worked to normalise and regulate the becoming child, the teachers themselves were also subjected to regulation and normalisation from the institution within which they worked:

Teacher Dee:

'The teachers [Foundation Phase teachers] tell us what they want the children to be able to do and what they need to know.'

Teacher Shari:

'I get help from the other ladies who are teaching the 3-year-old children ... we all plan together ... so we all teach the same thing. Teacher Thelma [the principal] also shows us what we must teach.'

Within this normative and performative regime, the choices that the teachers made for their practices were privileged and informed by the institution within which they worked. For example their planning processes and networks that they had set up were aligned to a 'dominant narrative of normativity and performativity in which the purpose of education is conformity with predetermined performance criteria'- getting the child ready for school and learning (Moss 2013:5). Within these contexts, conformity to the hegemonic discourse of readiness legitimated their role as the expert, which worked to enhance their professionalism and status. 
In South Africa, the legitimation of readiness is also evident within political discourse and government commissioned reports where early intervention is considered important as it 'substantially improve[s] cognitive ability and learner readiness for attainment of basic education' (Department of Basic Education 2012:2). From this perspective readiness is seen as part of a linear process where children progressively move towards a threshold of readiness, which, once passed, enables children to 'substantially improve[s] cognitive ability and learner readiness for attainment of basic education' (2012:2). Early childhood education and care is thus linked to a dominant discourse of readiness and child development that conceptualises early childhood education as a preparatory phase for the demands of basic education. These discourses connect to construct the image of the becoming child.

The teachers' constructions of the school-ready and ready-for learning child also points to how social class works to [re] produce the becoming child. At the two centres, children had differential access to educational opportunities, social networks and extracurricular activities and this was as a result of social class (see Ball 2013; Ball, Maguire \& Macrae 2000; Lareau 2003). Middle-class children at Cheerful Tots had access to commodities such as extra English classes, speech therapists, etc., to train, correct, classify and strengthen the normalising effect of the school-ready child (Foucault 1977). For children at Universal ECC, the material circumstances at the school and of the parents were social obstacles that made this access to extra educational opportunities difficult. Teacher Shari had to therefore use her knowledge, skills and experiences to support literacy learning at the centre. Teacher Shari was underqualified and the material conditions in which she enacted her practice were a 'space in which different but related norms are produced, responding-ecologically, to the local possibilities and limitations' (Blommaert et al. 2005:379). In responding to the limitations within the context, she provided support for literacy learning through repetition and observation:

'I observe each and every one of them, and when I see that there is a problem, I would help ... I do the same thing over and over again and I show them. We do the same things over and over again like singing songs, poems ... and other stuff.'

Through explicit teaching, repetition and observation, Teacher Shari ensured that children in her class had access to knowledge for participation in schooling. Recitation, demonstrations and observations can be construed as examples of socially mediated practices where the teacher and the children participated in joint and authentic acts (Rogoff 1990). However, these practices also worked to construct the docile, becoming subject, which legitimated the role of the practitioner as the primary transmitter and constructor of knowledge (Larson 2002). One can argue that repetition, recitation and showing children what to do, negate children's own cultural experiences and capacities thereby legitimating the subjectivity of the becoming child.

While Teacher Dee believed that her role was to get children ready for school, she also believed that children had a role to play in their own learning, thus seeing the child as having agency:

'I also learnt a lot from watching them ... from what they do and the seeing what they can do and how they can do it ... this is where you pick up what you can do with them. It is not me who has done it - it is the children who have done it ... I may have offered them the platform but they have done it themselves ... they have listened, they have heard and associated and they have learnt.'

The statements 'I have learnt a lot from watching them and it is not me who has done it' shows the child as an active agent who participates in knowledge construction and daily literacy experiences (James, Jenks \& Prout 1998). Teacher Dee believed that children were both capable and agentic because while she 'may have offered them the platform but they have done it themselves, they have listened, they have heard and associated and they have learnt'. However, these statements also reveal how this agentic, capable, becoming child was constructed.

In the middle-class context, children were provided with the physical spaces, objects, learning opportunities and guided support to facilitate their learning. Teacher Dee was thus working within the 'paradigm of the middle class' (Ball 2013:98) ways of becoming school ready. She therefore perpetuated the existing social order by ensuring that a literate child was constructed within the social realities of the context within which she taught. Constructing the child within middle-class ways of becoming school ready discounts the literate capital that children from other home and community contexts come with. In addition, viewing the child in terms of full human status in adulthood negates children's agency in terms of their present-day being on the road to becoming. Strandell (2007) argues for seeing the child as both being and capable in the present and becoming in the future as this is a more realistic representation of the child. It bridges the gap that makes children different from adults.

\section{Conclusion}

The aim of this article was to shed light on the dominant discourses of literacy, its constitutive nature and its effects. For both the teachers, literacy was about listening, speaking, reading and writing. This dominant discourse of literacy as skill converged to produce the image of the literate child with specific skills, competencies and knowledge, which was situated within the wider discourse of child development and school readiness. In constructing the literate child in this way, the discourses of child development and readiness converged to form the subjectivity of the becoming child.

Overall the approach used by the teachers for early literacy is problematic in the South African context. In using the template of the becoming child, the teachers position children in deficit ways, which negates children's capacities and agency. The unequal power relations deflect attention to how children interpret the literacy experiences created by the 
teachers. This occurs because teachers follow the normative developmental goals for literacy in terms of school readiness where children's engagement and participation were relegated to the learning of specific autonomous skills required for schooling.

Another area of concern is the approach to literacy as an autonomous skill. As a dominant approach, it is incompatible with addressing the concern of early childhood as a vehicle for transformation. In a plural society like South Africa, it is imperative that early childhood functions with a social justice agenda where attention is paid to how categories of difference (language, culture, race, class, gender, [dis]abilities) intersect to inform disparate literacy experiences for young children. Teachers should be encouraged to embrace an expanded approach to literacy, which takes into account the situational experiences of children in their different contexts. Who children are, what their capabilities are and what they need to know to be literate does not lie solely in the content of normative, standardised templates of child development and school readiness. Rather, this content has to be reinterpreted to develop situated practices, which are culturally relevant to young children in different contexts. For example, all children should be taught by knowledgeable teachers who use children's home language as a way of validating who children are.

In constructing the child as becoming, children's engagement and participation were relegated to the learning of specific autonomous skills required for school. Given this, one needs to ask the question as to how access, equity and participation can be widened for all children in South Africa to remove social class injustice. One way of enhancing access, equity and participation is to look at how children 'exist integrally in the world, in a reciprocally and actively interconnecting and transformative process of living, becoming and just being' (Alcock \& Haggerty 2013:22). Readiness as a 'normative developmental goal and the acquisition of particular knowledge and skills' leads to children being ranked and classified against a 'deficit model, a set of inappropriate, one-size-fitsall standards of readiness' for learning and school (Evans 2013:176; Whitebread \& Bingham 2011:11). This futurefocused reductionist view of the literate child and a preoccupation with what a literate child will become fails to recognise the 'complexity and multiplicity of who, how and where we become' (Giugni n.d.:1).

\section{Acknowledgements Competing interests}

The authors declare that they have no financial or personal relationships which may have inappropriately influenced them in writing this article.

\section{Authors' contributions}

C.D.M. was the project leader and responsible for the project design and the writing up of the article. H.B.E. made the conceptual contributions to the project and provided the final editing and reading of the text.

\section{References}

Alcock, S. \& Haggerty, M., 2013, 'Recent policy developments and the "schoolification" of early childhood care and education in Aotearoa New Zealand', Early Childhood Folio 17(3), 21-26.

Baker, C., 1998, "'Childhood" in the emergence and spread of U.S. public schools', in T.S. Popkewitz \& M. Brennan (eds.), Historical constructions of the reasoning of schooling, pp. 117-143, Teacher College Press, New York.

Ball, S.J., 2013, Foucault, power and education, Routledge, New York.

Ball, S.J., Maguire, M. \& Macrae, S., 2000, 'Space, work, and the "New Urban Economics"', Journal of Youth Studies 3, 279-300. http://dx.doi.org/10.1080/ 713684377

Barton, D. \& Hamilton, M., 2000, 'Literacy practices', in D. Barton, M. Hamilton \& R. Ivanic (eds.), Situated literacies: Reading and writing in context, pp. 7-16, Routledge, New York.

Baynham, M.B. \& Prinsloo, M., 2009, The future of literacy studies, Macmillan, Basingstoke, UK.

Berk, L.E., 2009, Child development, 8th edn., Pearson, Boston, MA

Blommaert, J., Muyllaert, N., Huysman, M. \& Dyers, C., 2005, 'Peripheral normativity: Literacy and production of locality in a South African township school', Linquistics and Education 16, 378-403. http://dx.doi.org/10.1016/j.linged.2006.03.001

Brown, C.P., 2010, 'Balancing the readiness equation on early childhood education reform', Journal of Early Childhood Research 8(2), 133-160. http://dx.doi.org/10. $1177 / 1476718 \times 09345504$

Burman, E., 2008, Deconstructing developmental psychology, 2nd edn., Routledge, East Sussex.

Cannela, D., 1997, Deconstructing early childhood education: Social justice and revolution, Peter Lang, New York.

Cannold, L., 2001, 'Interviewing adults', in G. MacNaughton, S.A. Rolfe \& I. SirajBlatchford (eds.), Doing early childhood research: International perspectives on theory and practice, pp. 175-192, Open University Press, Buckingham.

Carabine, J., 2001, 'Unmarried motherhood 1830-1990: A genealogical analysis', in M. Wetherell, S. Taylor \& S.J. Yates (eds.), Discourse as data: A guide for analysis, pp. 267-310, Sage, London.

Cohen, L., Manion, L. \& Morrison, K., 2011, Research methods in education, 7th edn., Routledge, London.

Comber, B, 1996, 'The discursive construction of literacy in a disadvantaged school', unpublished $\mathrm{PhD}$ thesis, James Cook University.

Department of Basic Education, 2012, National report 2012: The state of literacy teaching and learning in the foundation phase, Department of Basic Education, Pretoria.

Department of Education, 2001, Education white paper 5 on early childhood development: Meeting the challenges of early childhood development in South Africa, Department of Education, Pretoria.

Department of Education, 2005, National integrated plan for early childhood development in South Africa 2005-2010, UNICEF, Pretoria.

Department of Education, 2007, Progress report to the Minister of EducationManagerial Committee on learner retention in the South African schooling system, viewed 13 February 2015, from http://www.info.gov.za/view/DownloadFile Action?id=79404

Department of Education, 2012, National report 2012: The state of literacy teaching and learning in the foundation phase, Department of Education, Pretoria.

Department of Education \& UNICEF, 2009, National early learning standards for children birth to four, Department of Education, Pretoria.

Department of Education \& UNICEF, 2015, The South African National Curriculum framework, Department of Education, Pretoria.

Department of Social Development, 2006, Guidelines for early childhood development services, Department of Social Development, Pretoria.

Ebrahim, H.B., 2010, 'Tracing historical shifts in early care and education', Journal of Education 48, 1-17.

Evans, K., 2013, “'School readiness": The struggle for complexity', Learning Landscapes 7(1), 171-186.

Foucault, M., 1972, The archaeology of knowledge, transl. A.M. Sheridan Smith, Routledge, London.

Foucault, M., 1977, Discipline and punish: The birth of the prison, Allen Lane, London.

Foucault, M., 1980, in C. Gordon (ed.), 'Truth and power', in Power/knowledge: Selected interviews and other writings 1972-1977, pp. 109-133, Harvester, Brighton, UK.

Foucault, M., 1982, 'Afterword: The subject and power', in H.L Dreyfuss \& P. Rabinow (eds.), Michael Foucault: Beyond postructuralism and hermeneutics, pp. 10-49, The Harvester Press, Brighton.

Foucault, M., 1984, 'Nietzche, genealogy, history', in P. Rabinow (ed.), The Foucault reader, pp. 76-100, Pantheon Books, New York.

Foucault, M., 1988a, 'Technologies of the self (A Seminar with Michael Foucault at the University of Vermont, October 1982)', in L.H. Martin, H. Gutman \& P.H. Hutton (eds.), Technologies of the self: A seminar with Michael Foucault, University of Massachusetts Press, Amherst, MA.

Foucault, M., 1988b, 'Technologies of the self', in L.H. Martin, H. Gutman \& P.H. Hutton (eds.), Technologies of the self: A seminar with Michel Foucault, pp. 16-50, Tavistock, London. 
Grosz, E., 1990, 'Inscriptions and body-maps: Representation and the corporeal', in T. Threadgold \& A. Cranny-Francis (eds.), Feminine, masculine and representation, pp. 62-74, Allen \& Unwin, Sydney.

James, A., Jenks, C. \& Prout, A., 1998, Theorizing childhood, Polity Press, Cambridge, UK.

Kagan, S.L., 2007, 'Readiness-multiple meanings and perspectives', in M. Woodhead \& P. Moss (eds.), Early childhood and primary education: Transitions in the lives of young children, pp. 12-14, Open University Press, Milton Keynes.

Lareau, A., 2003, Unequal childhoods: Class, race, and family life, University of California Press, Berkely, CA.

Larson, J., 2002, 'Construction of commodified pedagogy on students participation in literacy events', Journal of Early Childhood Literacy 2(1), 65-95. http://dx.doi. org/10.1177/14687984020021004

Lee, N., 2001, Childhood and society: Growing up in an age of uncertainty, Open University Press, Buckingham.

Lister, R., 2007, 'Why citizenship: Where, when and how children?', Theoretical Inquiries in Law 8(2), 693-718. http://dx.doi.org/10.2202/1565-3404.1165

Mashiya, N., 2011, 'IsiZulu and English in Kwa-Zulu Natal rural schools: How teachers fear failure and opt for English', South African Journal of Childhood Education 1(1), 19-31. http://dx.doi.org/10.4102/sajce.v1i1.71

Maykut, P. \& Morehouse, R., 1994, Beginning qualitative research: A philosophical and practical guide, Falmer Press, London.

McGushin, E., 2011, 'Foucault's theory and practice of subjectivity', in D. Taylor (ed.) Michael Foucault: Key concepts, pp. 127-142, Acumen, Durham, NC.

Meier, C., 2014, 'Windows of opportunity: Early childhood development prospects in South Africa', Journal of Social Science 40(2), 159-168.

Meisels, S.J., 1999, 'Assessing readiness', in R.C. Pianta \& M.J. Cox (eds.), The transition from Kindergarten, pp. 39-66, A series from the National Centre for Early Development and Learning, Paul H. Brookes Publishing, York.

Moss, P., 2012, 'Readiness, partnership, a meeting place? Some thoughts on the possible relationship between early childhood and compulsory school education' Forum 54(3), 355-368. http://dx.doi.org/10.2304/forum.2012.54.3.355

Moss, P., 2013, 'The relationship between early childhood and compulsory education A properly political question', in P. Moss (ed.), Early childhood education and compulsory education: Reconceptualising the relationship, pp. 2-49, Routledge, Oxon.

Naidoo, U., Reddy, K. \& Dorasamy, N., 2014, 'Reading literacy in primary school in South Africa: Educators perspectives on factors affecting reading literacy and strategies for improvement', International Journal of Educational Sciences $7(11)$ 155-167.
Popkewitz, T.S. \& Bloch, M.N., 2001, 'Administering freedom: A history of the present-rescuing the parent to rescue the child for society', in K. Hultqvist \& G. Dahlberg (eds.), Governing the child in the new millennium, pp. 85-111, Routledge, New York.

Pretorius, E.J. \& Machet, M.P., 2004, 'Literacy and disadvantage: Learners' achievements in the early primary school years', Africa Education Review 1(1), 128-146. http://dx.doi.org/10.1080/18146620408566274

Rogoff, B., 1990, Apprenticeship in thinking: Cognitive development in social context, Oxford University Press, Oxford.

Sherry, K. \& Draper, C.E., 2013, 'The relationship between gross motor skills and school readiness in early childhood: Making the case in South Africa', Early Childhood Development and Care 183(9), 1293-1310. http://dx.doi.org/10.1080/ 03004430.2012.721358

Silverman, D., 2009, Doing qualitative research, 3rd edn., Sage, London, UK.

Spaul, N., 2013, 'Poverty \& privilege: Primary school inequality in South Africa', International Journal of Educational Development 33(5), 436-447. http://dx.doi. org/10.1016/j.ijedudev.2012.09.009

Stern, D.N., 2000, The interpersonal world of the infant, Basic Books, New York.

Strandel, H., 2007, 'Doing reality with play: Play as a children's resource in organising everyday life in daycare centres', Childhood 14, 47-66.

Street, B.V., 1984, Literacy in theory and practice, Cambridge University Press, UK.

Trudell, B., Dowd, J., Piper, B. \& Bloch, C., 2012, 'Early grade literacy in Africa classrooms: Lessons learned and future directions', paper prepared for the Triennale Meeting, Association for the Development of Education in Africa, Ouagadoudou, Bukina Faso, February 12-17, 2012.

Unsworth, L., 1988, 'Whole language or procedural display? The social context of popular whole language activities', Australian Journal of Reading 11(2), 127-137.

Unsworth, L., 2001, Teaching multiliteracies across the curriculum: Changing contexts of text and image in classroom practice. Open University Press, UK.

Uys, M., Van der Walt, J., Van den Berg, R. \& Botha, S., 2007, 'English medium of instruction: A situation analysis', South African Journal of Education 27, 69-82.

Van der Berg, S., Girdwood, E., Shepherd, D., Van Wyk, C., Kruger, J., Viljoen, J. et al., 2013. The impact of the introduction of grade $R$ on learning outcomes, Stellenbosch University, Stellenbosch.

Whitebread, D. \& Bingham, S., 2011, 'School Readiness: a critical review of perspectives and evidence'. 